\title{
Preoperative anemia and female gender as risk factors for transfusion in patients undergoing coronary artery bypass grafting with a restrictive transfusion strategy
}

\author{
Muharrem Kocyigit ${ }^{1}$, Ahmet Gullu ${ }^{1}$, Ozgen Ilgaz Kocyigit ${ }^{1}$, Sahin Senay ${ }^{1}$, Fevzi \\ Toraman $^{1}$, and Cem Alhan ${ }^{1}$ \\ ${ }^{1}$ Acibadem Mehmet Ali Aydinlar University
}

April 22, 2021

\begin{abstract}
Background: Red blood cell (RBC) transfusion increases morbidity and mortality after cardiac surgery. Despite the use of patient blood management methods, blood transfusions may still be needed in cardiac surgery. This study aims to determine the risk factors for blood transfusions in isolated coronary bypass graft surgery with the use of a restrictive transfusion strategy along with individualized patient blood management. Methods: A total of 198 consecutive patients (28 females, 170 males; age range 38-87) who underwent isolated CABG surgery in single private hospital using a restrictive transfusion strategy between April 2015 and October 2020 were included in the study. Patients were divided into two groups: with RBC transfusion and without RBC transfusion. Preoperative, intraoperative, and postoperative values were compared between groups. The risk factors for transfusion and transfusion probability were analyzed. Results: Preoperative hematocrit level and female gender (OR: $0.752 ; 95 \%$ CI $0.639-0.884 ; \mathrm{p}=0.001$; OR: 7.874; 95\% CI 1.678-36.950; $\mathrm{p}=0.009$, respectively) were the statistically significant independent risk factors for red blood cell transfusion. In female patients, the RBC transfusion probability was $61.08 \%$ when the preoperative hematocrit was $30 \%$. The intensive care unit and hospital stay were longer in the blood transfusion group. Conclusions: The risk factors for RBC transfusion were preoperative anemia and female gender in isolated CABG surgery with restrictive blood transfusion strategies. Keywords: anemia, blood transfusion, coronary artery bypass, patient blood management, restrictive blood transfusion
\end{abstract}

\section{Hosted file}

Preoperative anemia and female gender.pdf available at https://authorea.com/users/346329/ articles/519156-preoperative-anemia-and-female-gender-as-risk-factors-for-transfusionin-patients-undergoing-coronary-artery-bypass-grafting-with-a-restrictive-transfusionstrategy

\section{Hosted file}

Figure 1.pdf available at https://authorea.com/users/346329/articles/519156-preoperativeanemia-and-female-gender-as-risk-factors-for-transfusion-in-patients-undergoingcoronary-artery-bypass-grafting-with-a-restrictive-transfusion-strategy

\section{Hosted file}

Table 1.pdf available at https://authorea.com/users/346329/articles/519156-preoperativeanemia-and-female-gender-as-risk-factors-for-transfusion-in-patients-undergoingcoronary-artery-bypass-grafting-with-a-restrictive-transfusion-strategy

\section{Hosted file}


Table 2.pdf available at https://authorea.com/users/346329/articles/519156-preoperativeanemia-and-female-gender-as-risk-factors-for-transfusion-in-patients-undergoingcoronary-artery-bypass-grafting-with-a-restrictive-transfusion-strategy

\section{Hosted file}

Table 3.pdf available at https://authorea.com/users/346329/articles/519156-preoperativeanemia-and-female-gender-as-risk-factors-for-transfusion-in-patients-undergoing-

coronary-artery-bypass-grafting-with-a-restrictive-transfusion-strategy 